\title{
Instructional Strategies and Learning Styles as Predictors of High School students' Academic Performance in Physics Practicals in Kenya
}

\author{
Fanuel Wesonga, F. $\mathrm{M}^{1^{*}}$ and Catherine Aurah ${ }^{1}$ \\ ${ }^{1}$ Masinde Muliro University of Science and Technology, Kenya
}

\begin{abstract}
The desire of every teacher and every educator is to improve academic performance in schools and colleges. Meaningful teaching and learning requires flexibility, creativity and responsibility in order to provide a conducive learning environment able to respond to the learner's individual needs. A host of research has been conducted to investigate various factors that influence academic performance. Among such factors is the preferred learning styles of learners. A quasi experimental pre-test post-test non-equivalent control group design was conducted to investigate how three learning styles (visual, auditory and kinaesthetic) and three teachers' instructional strategies (guided-inquiry, cooperative learning and direct instruction) predict academic performance (achievement test scores and acquisition of science process skills) in Physics practical work while controlling for gender. A sample of five hundred and nineteen (519) form three physics students were selected through multistage sampling procedures (purposive sampling, proportionate stratified random sampling and simple random sampling). Physics Achievement Tests 1 and 2 (PAT1 \& PAT2), Learning Style Questionnaire and Physics Process Skills Checklist (PPSC).Teachers' Instructional Guides on Guided-Inquiry (TIGITS), Cooperative (TIGCTS) and Direct Instructional Strategy (TIGDITS) were used to collect quantitative data.. Validity and reliability of the instruments were assessed. Data were analysed using multiple Linear Regression test. Results indicated that while Teachers' Instructional Strategies contributed significantly to the model $(\mathrm{B}=$ 3.266, $\mathrm{p}<.05)$, Students' learning Styles did not $(\mathrm{B}=.717, \mathrm{p}=.412)$. These findings have implications to educators, teachers, learners, and ministry of education stakeholders. Recommendations are provided.
\end{abstract}

Keywords: Instructional practices, Learning Styles, Academic Performance, Physics practicals

\section{Introduction}

Meaningful teaching and learning requires flexibility, creativity and responsibility in order to provide a conducive learning environment able to respond to the learner's individual needs. Both theory and research support the view that beyond the experiential evidence that pervasive uniformity in teaching fails many learners, there is reason in both theory and research to support a movement towards an instruction attentive to students' variance manifested in at least three areas: the student's readiness, interest, and learning profile (Tomlinson, 2001). However, recent research suggests that the style by which one learns and applies knowledge is an important characteristic to consider in the aggregate educational processes (Graf, Lin, \& Kinshuk, 2008; Kolb \& Kolb, 2009; Syler et al., 2006; Thor- ton, Haskell \& Libby, 2006; Zualkernan, Allert, \& Qadah, 2006). An increasing amount of research in the last two decades points out that the interactive process between individual student and the teacher is very important in determining the nature and quality of learning and development that result from instruction (Adunola 2011; Ayeni,2011; Nwagbo, 2001). According to Ayeni (2011), teaching is a continuous process that involves bringing about desirable changes in learners through use of appropriate methods. Adunola (2011) indicated that in order to bring desirable changes in students, teaching methods used by educators should be best for the subject matter. Furthermore, Bharadwaj \& Pal (2011) maintained that teaching methods work effectively mainly if they suit learners' needs since every learner interprets and responds to questions in a unique way (Chang, 2010). As such, alignment of teaching methods with students' needs and preferred learning influence students' academic attainments (Zeeb, 2004). In Kenya, one of the prevailing challenges that high school teachers face is related to matching the teaching strategies with the students' 
learning styles in order to improve academic achievement. A shift from the traditional to a progressive mode of teaching to an increased interest in learners' individual differences is the main concern of educators.

According to Fleming's (1992) VAK model, an acronym for the Visual (V), Auditory (A), and the Kinaesthetic (K) sensory modalities, learners are provided with a profile of their learning styles, based on the sensory modalities which are involved in taking in information and that learning styles are unique to each and every person. There may not be general classifications for each and every style. Visual learners prefer to learn via the visual channel. Therefore, they like to read a lot, which requires concentration and time spent alone. Visual learners need the visual stimulation of bulletin boards, video and movies. They must have written directions if they are to function well in the classroom". (Oxford, 1995, p. 35). Auditory learners enjoy the oral-aural learning channel. Thus, they want to engage in discussions, conversations, and group work. These students typically require only oral directions". (Oxford, 1995, p. 36). Kinesthetic learners are those who "imply total physical involvement with a learning environment such as taking a field trip, dramatizing, pantomiming, or interviewing". (Kinsella, 1995, p. 172). Each person possesses a combination of two or three of these styles. The students' ability to solve problems varies depending on their learning style. According to Aljaberi (2015), the most frequently preferred learning style shows better performance than other learning styles. The ability to understand students' learning styles can increase educational outcomes. Teachers should take into consideration of these learning styles in their classroom activities. This can help students gain competence in what they learn and improve on their academic achievement (Ibrahim \& Hussein, 2016). Research has also shown that most students learn best when the style of presentation is aligned with their preferred learning style. It is important for teachers to understand the students' learning styles and also for students to understand their own learning styles (Vanessa, 2011). By understanding different learning styles, teachers may gain insights into ways of making academic information more accessible to various groups of learners and an increased awareness of individual learning styles can help educators impart new information in a memorable way (Brady, 2013).

Likewise, if students are aware of their preferred learning styles they will be able to recognize their strengths and weaknesses, and by doing so, they can then develop strategies for effective learning. Just as the learners learn in different ways, so also teachers teach in different ways. In fact, Alavi and Toozandehjani (2017) concluded that having a background of the learning styles of students can enhance their learning and at the same time help students strengthen self-actualization. Teevan, Michael and Schlesselman (2011) also emphasize that knowledge of the learning styles can help facilitate teachers to employ suitable teaching strategies and methods to nurture students' academic performance. This will also provide both teachers and students positive feedback on their strengths and weaknesses in the teaching and learning scenario. Likewise, knowledge of the learning styles can provide implications to curriculum design allowing teachers to implement a learner-centered curriculum model in the classroom. Dalmolin, Mackeivicz, Pochapski, Pilatti and Santos (2018) suggest that determining the learning styles of students will ultimately improve their educational experience. Previous exiting literature confirms that learning styles predict students' academic performance. Jiraporncharoen, Angkurawaranon, Chockjamsai, Deesomchok and Euathrongchit (2015) studied learning styles and academic achievement of undergraduate students in Thailand found out a positive association between the two. Barman, Aziz and Yusoff (2014) also studied the learning style awareness and academic performance of students concluded that students 'awareness of their strengths such as learning style and how to utilize their strengths may improve their academic performance.

Another variable investigated in this study is instructional strategy. The primary purpose of teaching at any level of education is to bring a fundamental change in the learner (Tebabal \& Kahssay, 2011). To facilitate the process of knowledge transmission, teachers should apply appropriate teaching methods that best suit specific objectives and level exit outcomes. Traditionally, many teachers widely applied teacher-centered methods to impart knowledge to learners comparative to student-centered methods. Until today, questions about the effectiveness of teaching methods on student learning have consistently raised considerable interest in the thematic field of educational research (Hightower etal., 2011). Moreover, research on teaching and learning 
constantly endeavour to examine the extent to which different teaching methods enhance growth in student learning. Quite remarkably, regular poor academic performance by the majority students is fundamentally linked to application of ineffective teaching methods by teachers to impact knowledge to learners (Adunola, 2011).Substantial research on the effectiveness of teaching methods indicates that the quality of teaching is often reflected by the achievements of learners. According to Ayeni (2011), teaching is a process that involves bringing about desirable changes in learners so as to achieve specific outcomes. In order for the method used for teaching to be effective, Adunola(2011) maintains that teachers need to be conversant with numerous teaching strategies that take recognition of the magnitude of complexity of the concepts to be covered.

The inability of a teacher to teach Science in an effective way is classified as one of the factors leading to student's poor performance in the subject both in internal and external examinations. It is believed that persistent poor academic performance by majority of learners is due to use of ineffective instructional strategies by teachers to transfer knowledge to the learners (Adunola, 2011). Research on the effectiveness of the instructional strategies shows that the worth of teaching is reflected by the performance of learners (Ayeni, 2011).Therefore, teachers are responsible to be conversant with several teaching strategies that can make them transfer knowledge on various concepts to be covered. Therefore, several instructional strategies have been established based on the theory that meaningful learning takes place when the learners are actively involved in the knowledge getting process than being passive (Njoku, 2004). These include peer tutoring, cooperative learning, Guided inquiry, project and inquiry based teaching strategies.

Physics is one of the science subjects that occupies a unique position in national development. In Kenya, the secondary school physics curriculum is designed to enhance students' investigation into natural phenomena, deepen students' understanding and interest in physical sciences and to encourage students' ability to apply scientific knowledge to everyday life (Ministry of Education, 2009). Physics is therefore an important science subject and stands as the bedrock to the learning of science disciplines such as; Medicine, Pharmacy, Nursing, Engineering, Architecture that are of great, the students' academic achievement and science process skills acquisition is still poor globally and Kenya is not an exception.

The interplay of learning style preferences, instructional strategies and academic performance of students enrolled in high school and taking physics in Kenya prompted the researcher to investigate Teachers' Instructional Strategies and Students' Learning Styles as Predictors of Academic Performance in Physics Practical Work among High School Students in Kenya. Recognizing students' innate learning dispositions and how teachers teach will be a basis for schools to design and implement educational interventions with the goal of enhancing students' academic performance and the quality of their learning experiences. In this study, 3 instructional strategies(such as guided-inquiry, cooperative and direct instruction) and 3 learning styles (visual, auditory and kinaesthetic) are considered in investigating the influence of teachers' instructional strategies and students' learning styles on academic performance which is used to mean academic achievement in physics practical and acquisition of physics process skills

\section{Research Objectives and Hypotheses}

The study was guided by two objectives: (1) To examine differences in academic performance by instructional method and learning styles, while controlling for gender effects (2) To determine interactive effects of instructional strategies and learning styles on students' academic performance, from which the following hypotheses were formulated:

H01: Students' academic performance in physics does not differ by Instructional strategies and learning styles

H02: Instructional strategies and learning styles do not have interactive effects on students' academic performance 
Independent variables were Instructional Approaches (Guided, Cooperative and Direct) and Learning Styles (Visual, Auditory and Kinesthetic (VAK)). Dependent variables are Academic Achievement as measured by a physics achievement test, and Physics Process Skills as measured by Process Skills checklist, while the intervening variable was gender

\section{Methodology}

\section{Research Design}

The study adopted a quasi-experimental pretest - posttest non-equivalent control group design. The design included instructional strategy at three levels (two treatment groups comprising Guided-inquiry instructional strategy (Experimental group 1), Cooperative learning strategy (Experimental group 2) as well as a control group (the direct instructional strategy). Students' learning styles in physics were also investigated at three levels (visual, auditory and kinaesthetic) with respect to students' academic achievement and acquisition of science process skills in physics practical work. Gender was also investigated as an intervening variable.

\section{Sampling}

Multi-stage sampling technique was used which included Purposive, stratified random sampling, and simple random sampling techniques to select a sample of $\mathrm{n}=519$ form three students from 21 selected schools drawn from Navakholo Sub-County, Kakamega County in Kenya.

\section{Instruments}

A total of SIX instruments were used to collect quantitative data. These included: Physics Achievement Tests (PAT 1PAT2), consisting of physics practical skills questions, Learning Style Questionnaire, formulated by Barbe, (1979), with 30 multiple choice questions, and Physics Process Skills Checklist (PPSC), developed to assess process skills such as: Observation, Measuring, Inferring, Classifying and Predicting) and integrated process skills and 3 Teachers' Instructional Guides on Guided-Inquiry (TIGITS), Cooperative(TIGCTS) and Direct Instructional Strategy(TIGDITS)

\section{Results}

Data were cleaned and analysed both Descriptively using means and standard deviations and 2-Way Multivariate Analysis of Covariate (MANCOVA). Assumptions of MANCOVA were tested.

\section{Assumptions of MANCOVA}

Five assumptions were assessed. Normality was checked using histograms and the dependent variables followed a normal distribution for each group (see appendices A \& B). Covariates and dependent variables were measured at the interval scale and the two independent variables had three categorical, independent groups. There was an adequate sample size. For Homogeneity of variance between groups, there was homogeneity of variance-covariance matrices as tested by Box's M Test of Equality of Covariance Matrices which was nonsignificant as required $(\mathrm{p}=.398)$. Lastly for absence of multicollinearity, the dependent variables were not significantly correlated. 


\section{Descriptive Statistics}

Means and standard deviations for the dependent measures (Academic Achievement and Science Process Skills), teaching strategy (Direct, Cooperative and Guided) and student learning styles (Visual, Auditory and Kinaesthetic) variables are presented in Table 1.

Table 1:Means and Standard Deviations for Variables

\begin{tabular}{|c|c|c|c|c|c|c|}
\hline \multirow[b]{2}{*}{$\begin{array}{l}\text { Student's } \\
\text { Learning Styles }\end{array}$} & \multirow[b]{2}{*}{$\begin{array}{l}\text { Teachers' Instructional } \\
\text { Strategies }\end{array}$} & \multirow[b]{2}{*}{$\mathrm{N}$} & \multicolumn{2}{|c|}{$\begin{array}{l}\text { ACADEM } \\
\text { ACHIEVEMENT }\end{array}$} & \multicolumn{2}{|c|}{ PROCESS SKILLS } \\
\hline & & & Mean & $\begin{array}{l}\text { Std. } \\
\text { Deviation }\end{array}$ & Mean & $\begin{array}{l}\text { Std. } \\
\text { Deviation }\end{array}$ \\
\hline \multirow{4}{*}{ Visual } & Direct Instruction & 83 & 56.6627 & 16.17004 & 62.7590 & 13.84988 \\
\hline & Cooperative learning & 73 & 65.1233 & 16.19838 & 60.7123 & 13.19773 \\
\hline & Guided-Inquiry & 59 & 57.7458 & 17.99578 & 62.3051 & 15.30974 \\
\hline & Total & 215 & 59.8326 & 17.05543 & 61.9395 & 14.01571 \\
\hline \multirow{4}{*}{ Auditory } & Direct Instruction & 39 & 58.2821 & 16.12770 & 57.0000 & 13.42817 \\
\hline & Cooperative learning & 59 & 61.0339 & 19.72742 & 65.8475 & 15.46834 \\
\hline & Guided-Inquiry & 37 & 65.0000 & 17.06361 & 58.1351 & 13.15329 \\
\hline & Total & 135 & 61.3259 & 18.08018 & 61.1778 & 14.77890 \\
\hline \multirow{4}{*}{ Kinaesthetic } & Direct Instruction & 55 & 55.5455 & 15.53588 & 66.0000 & 14.09754 \\
\hline & Cooperative learning & 54 & 61.0926 & 16.12834 & 72.7963 & 14.89001 \\
\hline & Guided-Inquiry & 60 & 74.6500 & 14.25176 & 74.3333 & 12.71149 \\
\hline & Total & 169 & 64.1006 & 17.25083 & 71.1302 & 14.27392 \\
\hline \multirow{4}{*}{ Total } & Direct Instruction & 177 & 56.6723 & 15.90615 & 62.4972 & 14.13656 \\
\hline & Cooperative learning & 186 & 62.6559 & 17.39555 & 65.8495 & 15.19278 \\
\hline & Guided-Inquiry & 156 & 65.9679 & 17.92364 & 65.9423 & 15.36995 \\
\hline & Total & 519 & 61.6108 & 17.45305 & 64.7341 & 14.95394 \\
\hline
\end{tabular}

The results of the descriptive analyses demonstrated a range of 55.5 to 74.7 for academic achievement across teaching strategies and learning styles, with students under guided instruction and with Kinaethetic learning style scoring the highest mean, $M=74.7$ and students with Auditory preferred learning style and taught using Direct instruction scoring the lowest, $\mathrm{M}=55.5, \mathrm{SD}=15.5$ (possible range $0-100$ ) and no evidence of ceiling or floor effects $(M=61.6, S D=17.5)$. For Science Process skills, descriptive analyses demonstrated a range of $\mathrm{M}=57.0, \mathrm{SD}=13.4$ to $\mathrm{M}=74.3, \mathrm{SD}=12.7$ for academic achievement across teaching strategies and learning styles, with students under guided instruction and with Kinaethetic learning style scoring the highest mean, M= 74.7, $\mathrm{SD}=14.3$ and students with Auditory preferred learning style and taught using Direct instruction scoring the lowest, $\mathrm{M}=55.5, \mathrm{SD}=15.5$ (possible range $0-100)$ and no evidence of ceiling or floor effects $(\mathrm{M}=61.6, \mathrm{SD}$ $=17.5$ ).

Descriptive statistics by Gender showed interesting results where males did better in process skills $(\mathrm{M}=65.3$, $\mathrm{SD}=14.9$ for Males and $\mathrm{M}=63.1, \mathrm{SD}=14.8$ for females) while females outperformed boys in achievement test $(\mathrm{M}=65.4, \mathrm{SD}=17.3$, for females and $\mathrm{M}=60.3, \mathrm{SD}=17.3$ for Males). Historically, it is known that gender 
supremacy, stereotyping, attitude, domineering effect during practicals in co-educational schools makes males do better than females. This forms a basis for further research in this area.

\section{Factorial MANCOVA}

To understand whether the differences in students' academic achievement and Physics Process Skills by Instructional Strategy (3 groups: Guided, cooperative, individual) and Students' learning style (3 groups: Visual, Auditory, and Kinesthetic), were statistically significant, a Factorial MANCOVA was conducted. The results are reported in Table 2

Table 2:Results of Factorial MANCOVA

\begin{tabular}{|c|c|c|c|c|c|c|c|c|c|c|}
\hline \multirow[t]{3}{*}{ Source } & \multirow{2}{*}{\multicolumn{4}{|c|}{ Multivariate Tests }} & \multicolumn{6}{|c|}{ Univariate Tests } \\
\hline & & & & & \multicolumn{3}{|c|}{ Academic Achievement } & \multicolumn{3}{|c|}{ Science Process Skills } \\
\hline & $\mathrm{F}$ & $\begin{array}{l}\text { Wilks' } \\
\text { Lambda }\end{array}$ & p-value & $\mathrm{n} 2$ & $\mathrm{~F}$ & p-value & $\mathrm{n} 2$ & $\mathrm{~F}$ & p-value & $\mathrm{n} 2$ \\
\hline Instructstr & 8.714 & 0.934 & $<0.001 *$ & 0.034 & 17.01 & $<0.001 *$ & 0.064 & .355 & .701 & .001 \\
\hline Learnst & 0.523 & 0.996 & 0.719 & 0.002 & 0.121 & 0.886 & 0.000 & .883 & .414 & .004 \\
\hline Gender & 5.528 & 0.979 & $.005^{*}$ & 0.021 & 4.22 & $0.041 *$ & 0.008 & 6.997 & $.008^{*}$ & ,014 \\
\hline Instr*Gender & 4.899 & 0.962 & $0.001 *$ & 0.019 & 9.72 & $<0.001 *$ & 0.037 & .068 & .935 & 0.00 \\
\hline Learnst*Gender & 0.706 & 0.994 & 0.588 & 0.003 & 0.319 & 0.727 & .001 & 1.081 & .340 & .004 \\
\hline Instr*Learnsty & 0.947 & 0.985 & 0.477 & 0.008 & 0.696 & 0.595 & .006 & 1.291 & .272 & .010 \\
\hline Instr*Learbst*Gender & 1.208 & 0.981 & 0.291 & 0.010 & 1.127 & 0.343 & .009 & 1.274 & .279 & .010 \\
\hline
\end{tabular}

There is a statistically significant 2-way interaction between gender and instructional strategy, meaning that the effect of the intervention (instructional strategy) on the linear combination of the dependent variables (academic achievement and physics process skills) is not the same for males and females $(\mathrm{F}(4,515)=4.899 \mathrm{p}-.001$; Wilks' $\Lambda=.962)$. Main effects of Gender $(F(4,515)=5.528, \mathrm{p}<.005 ;$ Wilks' $\Lambda=.979)$ and instructional strategy $(F(4$, $515)=8.714 \mathrm{p}<.001 ;$ Wilks' $\Lambda=.934)$ were also statistically significant for linear combination of the dependent variables Academic achievement and physics process skills. This means the two independent variables uniquely influence the linear combination of the DVs

As a follow up on significant MANCOVA, univariate tests revealed a statistically significant 2 way interaction between gender and instruction for academic achievement only $F(2,515)=9.72, p<0.001)$. Instructional strategy had a statistically significant effect on academic achievement but not Physics process skills $(\mathrm{F}(2,515)=17.009$, $\mathrm{p}<0.001$, $\mathrm{n} 2=0.064)$. This may mean that the instructional strategies investigated may not be critical in acquisition of physics process skills. Gender had significant effects on both academic achievement and Physics process skills $(\mathrm{F}(2,515)=4.22, \mathrm{p}<0.041, \mathrm{n} 2=0.008 \&(\mathrm{~F}(2,515)=6.997, \mathrm{p}=0.008, \mathrm{n} 2=0.014$, respectively $)$.

Again, partial eta squared values are reported showing the amount of variance in the dependent

variables. For both DVs, magnitude of the difference was small, based on Cohen (1988) guidelines. Instruction accounts for $6.4 \%$ in academic achievement and $-.1 \%$ in science process skills. Learning styles account for no variance in academic achievement and only $0.4 \%$ in science process skills.

\section{Discussion of Results}

The result of hypothesis one showed that cooperative learning is the most effective instructional strategy for physics students with visual learning style on academic achievement. This might be due to the fact that 
cooperative learning exposes the students to more realities of life and they tends to work as scientist and acquire knowledge by themselves in which the teacher serves as a guide and correct their misconceptions (Kuhlman, 2016). The result also show that guided inquiry the most effective instructional strategy for physics students with visual learning style. Likewise the result show that guided inquiry the most effective instructional strategy for physics students with Kinaethetic learning style. The result is in agreement with the findings of Ikitde and Edet, (2013) that students with Students with Sensing/Intuitive learning styles perform better when taught with guided-inquiry teaching strategy. Demonstration teaching strategy is the most effective strategy in enhancing the achievement of students with Sequential/Global learning style. The result is also consistent with the findings of Hasan (2012) that preference of the guided inquiry sessions overreaches the better academic achievement superiority to work as a motivation power for keeping students engrossed in their tasks. Guided inquiry approach in teaching and learning sciences is recommended in terms of its inclusive effects. Either in the lab work or in the theoretical classes, students as long as they deal with different materials and sources relishing the midst of searching and answering questions critically, their science literacy, research skills and self confidence all are considerable and important targets during guided inquiry classes. The descriptive statistics on science process skills showed that direct instruction is the most effective instructional strategy for physics students with visual learning style. This might be due to the fact that that visual learners get more information from visual images such as pictures and diagrams(Akinbobola, 2015).The result of hypothesis two indicated that there was a statistically significant 2-way interaction between gender and instructional strategy. This meant that the effect of the instructional strategy on the linear combination of the dependent variables (academic achievement and physics process skills) was not the same for both males and females. This findings are in line with those of (Christian, 2014 ) that the combined effect of all variables accounted for only $22 \%$ of the total variance in the achievement of the students and this value was significant. However, the relative effect of the variables on students' achievement was found to be significant as well but the following fashion: learning strategies $>$ school location>gender>age. Age was the only variable with non-significant relative effect on students' achievement. This finding is consistent with earlier studies (Adunola, 2011, Ayeni, 2011) who concluded that effectiveness of teaching methods indicates that the quality of teaching is often reflected by the achievements of learners. And that teachers need to be conversant with numerous teaching strategies that take recognition of the magnitude of complexity of the concepts to be covered

\section{Conclusion}

Results revealed that instructional strategy and gender have a significant influence on how students learn physics, with Kinaesthetic learning style being superior in both process skills $(\mathrm{M}=71.13, \mathrm{SD}=14.27)$ and academic achievement $(\mathrm{M}=64.10, \mathrm{SD}=17.25)$. Furthermore, Guided instruction was superior for academic achievement $(\mathrm{M}=65.97, \mathrm{SD}=17.92)$ while cooperative strategy was superior for physics process skills $(\mathrm{M}=65.85, \mathrm{SD}=15.19)$.

In addition, results indicated that male students tend to do better in physics process skills across all the three types of instructional strategies, whereas girls do better in academic achievement across two types of instructional strategies (Direct and Cooperative).

\section{Recommendations}

Based on the findings from this study, it is recommended that teachers make a deliberate attempt to explore learners' preferred learning styles and have them integrated into educational programmes. In addition, the teachers may need to vary instructional strategies to reach out to as many students as possible. These findings have far-reaching implications on policies, planning, classroom practice of teachers and educators 


\section{References}

Adunola, O. (2011), "The impact of teachers, teaching methods on the academic performance of primary school pupils in web ode local area of organization state," Ego Booster Books, Ogun state, Nigeria. Alavi and Toozandehjani (2017)

Akinbobola, A. O. (2015). Effects of learning styles and instructional strategies on students' achievement in Nigerian senior secondary school physics. Advances in Physics Theories and Application, 41, 20-29.

Alavi, S., \& Toozandehjani, H. (2017). The Relationship between Learning Styles and Students' Identity Styles. Open Journal of Psychiatry, 7(02), 90.

Aljaberi, Nahil M. (2015). University Students' Learning Styles and Their Ability to Solve Mathematical Problems. International Journal of Business and Social Science, Vol. 6, No. 4(1); April 2015. (Online), (http://ijbssnet.com/journals/Vol_6_No_4_1_April_2015/18.pdf.),

Ayeni, A.J (2011), "Teacher professional development and quality assurance in Nigeria Secondary School, "World Journal of education, 1(2): 143-149. Barman, Aziz and Yusoff (2014)

Bharadwaj, B. K. \& Pal, S. 2011. Data Mining: A prediction for performance improvement using classification, International journal of computer Science and Information security (IJCSIS),9(4), 136-140.

Barman, A., \& Muhamed Yusoff, Y. (2014). Learning style awareness and academic performance of students. South-East Asian Journal of Medical Education, 8(1), 47-51.

Brady, C. L. (2013). Understanding Learning Styles: Providing the Optimal Learning Experience. International Journal of Childbirth Education, 28(2).

Chang, W. (2002, April). The impact of constructivist teaching on students' perceptions of teaching and learning. Paper presented at the Annual Meeting of the National Association for Research in Science Teaching, New Orleans, LA.

Christian, M. (2014). Learning Strategies, Age, Gender and School-location as Predictors of Students' Achievement in Chemistry in Rivers State, Nigeria. Research on Humanities and Social Sciences, 4,(21), 121, 127.

Dalmolin A., Mackeivicz, G., Pochapski, M., Pilatti, G., \& Santos, F. (2018). Learning styles preferences and elearning experience of undergraduate dental students. Rev Odontol UNESP, 47(3), 175-182. https://doi.org/10.1590/1807-2577.05118

Fleming, N.D., Mills, C. (1992). Not Another Inventory, Rather a Catalyst for reflection to improve the academy. Professional and Organisational Development Network in Higher Education. pp. 137-55. Retrieved on July 14, 2014 from:

http://digitalcommons.unl.edu/cgi/viewcontent.cgi?article=1245\&context=podimproveacad

Graf, S., Lin, T., and Kinshuk (2008). The relationship between learn-ing styles \& cognitive traits-Getting additional information for im-proving student modeling. Computers in Human

Hasan, A. S. A. (2012). The effects of guided inquiry instruction on students' achievement and understanding of the nature of science in environmental biology course (Doctoral dissertation, The British University in Dubai (BUiD)).

Hightower, A.M. (2011). Improving Student learning by supporting quality teaching: Key issues, effective strategies, "Editorial projects in education. Ibrahim \& Hussein (2016).

Ibrahim, R. H., \& Hussein, D. A. (2016). Assessment of visual, auditory, and kinesthetic learning style among undergraduate nursing students. Int J Adv Nurs Stud, 5, 1-4.

Jiraporncharoen, W., Angkurawaranon, C., Chockjamsai, M., Deesomchok, A., \& Euathrongchit, J. (2015). Learning styles and academic achievement among undergraduate medical students in Thailand. Journal of 134 Educational Evaluation for Health Professions, 12(38). doi: 10.3352/jeehp.2015.12.38.

Kinsella, K. (1995). Understanding and empowering diverse learners. In J. M. Reid (ed.), Learning Styles in the ESL/EFL Classroom (pp. 108-117). Boston: Heinle \& Heinle Publishers. 
Kolb, A., \& Kolb, D. (2009). The learning way: Meta-cognitive aspects of experiential learning. Simulation \& Gaming, 40(3), 297- 327.

Kuhlman, J. L. (2016). Using Cooperative Learning to Increase Achievement of Urban Learners in Math and Reading through Strong Interpersonal Relationships.

Mary, L.W.(2011). Students' learning style preferences and teachers' instructional strategies: correlations between matched styles and academic achievement. Unpublished Doctoral Dissertation, Liberty University, Lynchburg, VA

MOEST (2009). Republic of Kenya, National ICT policy strategy for Education and Training. Nairobi, Government Press.

Njoku, Z .C., (2004). Fostering the application of Science education research findings in Nigeria classrooms: strategies and needs development. M.A.G Aka i.e. (ed) 45 Annual conference proceedings of Science teacher Association of Nigeria (PP217-222): Ibadan; Heinemann Educational Books Limited. Syler et al., 2006;

Nwagbo, C. (2001). The Relative Effectiveness of divided and Expository Methods on the Achievement in Biology of Students of Different Levels of Scientific Literacy. Journal of Science Teachers Association of Nigeria (JSTAN) pp. 271-291.

Oxford, R. L. (1995). Gender differences in learning styles: What do they mean? In J. M. Reid (ed.), Learning styles in the ESL/EFL classroom (pp. 34-46). Boston: Heinle \& Heinle.

Tebabal, A. \& Kahssay, G. (2011).“The effects of student centered approach in improving students' graphical interpretation skills and conceptual understanding of kinematical motion”, Lat. A.M.J Phy.Edu, 5 (2) 374.

Teevan, C.J., Michael, L.I., Schlesselman, L.S. (2011). Index of Learning styles in a U.S. school of pharmacy. Pharmacy Pract, 9(2), 82-87. http://dx.doi.org/10.4321/S1886- 36552011000200004

Thorton, B., Haskell, H., \& Libby, L. (2006). A comparison of learning styles between gifted and non-gifted high school students. Individual Differences Research, 4, 106-110.

Tomlinson, C. (2001). How to differentiate instruction in mixedability classrooms (2nd ed.). Alexandria, VA: Association for Supervision and Curriculum Development.

Zualkernan, I., Allert, J., \& Qadah, G. (2006). Learning styles of com-puter programming students: A Middle Eastern \& American com-parison. IEEE Transactions on Education, 49, 443-450. http://dx.doi.org/10.1109/TE.2006.882366

Zeeb, M. S. (2004). Improving student success through matching learning and teaching styles. Retrieved from http://www.creativelearningcentre.com/downloads/lsia/

Zeeb\% 20LSA\%20research\%20pilot\%20edited\%20US.pdf on 25/7/2012.

Zywno, M.S. (2002)., Instructional Technology, Learning Styles and Academic Achievement, Proceedings of 2002 ASEE Annual Conference and Exposition, Session 2422, Montreal, Quebec, Canada, 
Fanuel Wesonga, F. M and Catherine Aurah / Instructional Strategies and Learning Styles....

\section{Appendices}

Appendix A:Histogram Depicting Normality of Academic Achievement Data

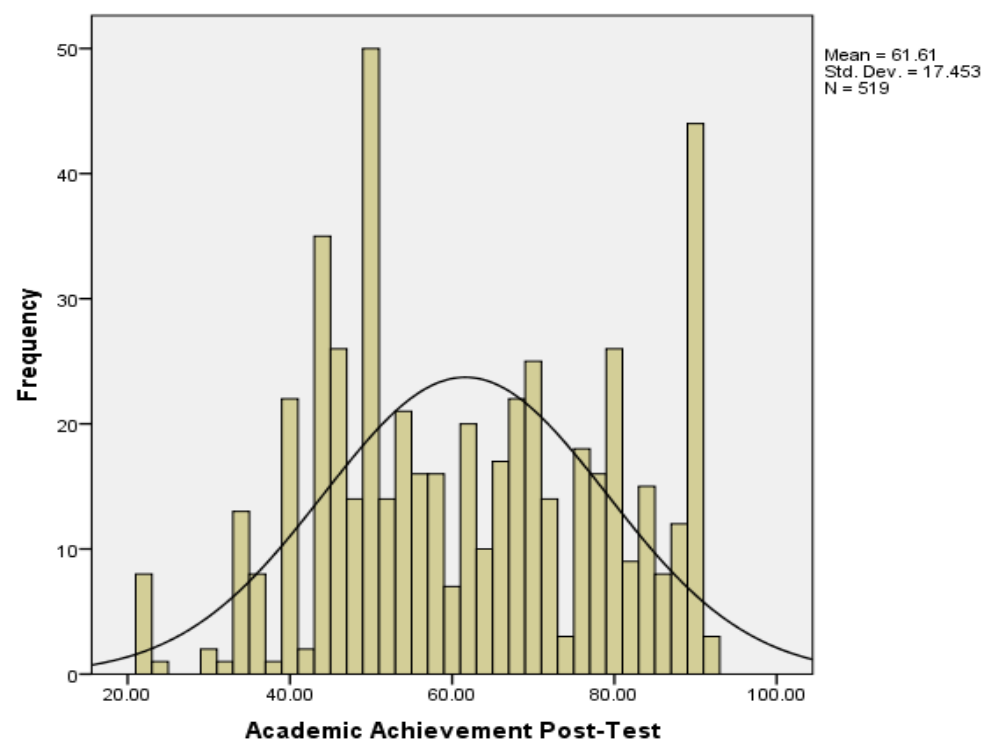

Appendix B:Histogram Depicting Normality of Physics Process Skills Data

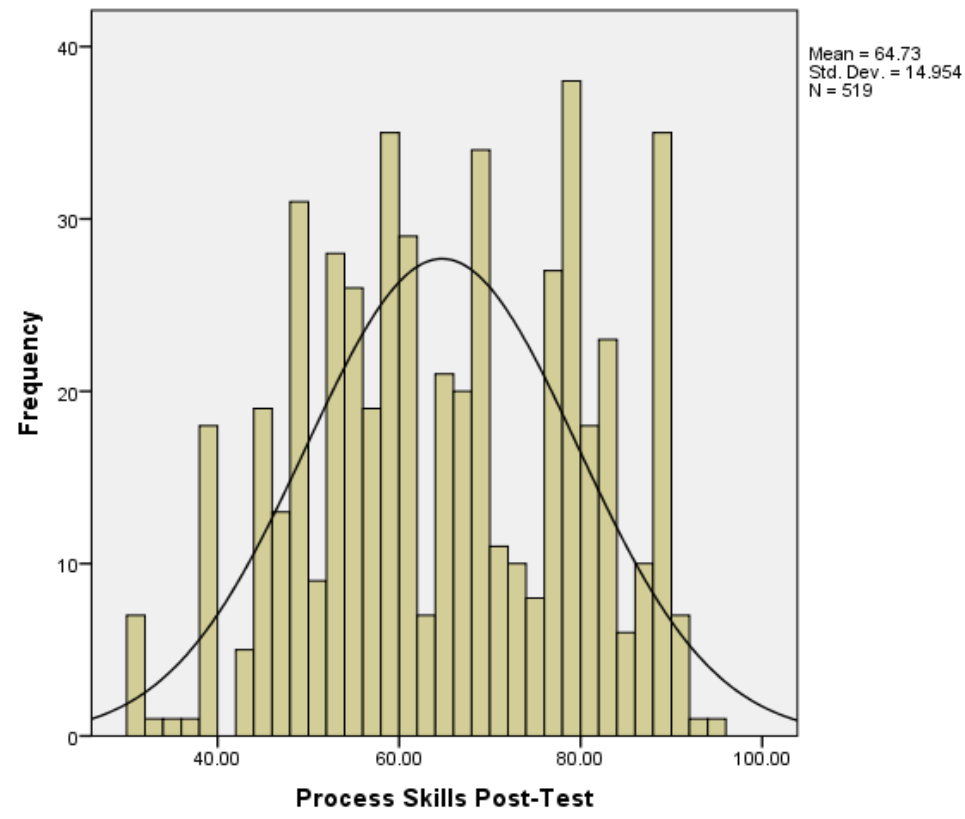




\section{Table 2: Descriptives by Gender}

\begin{tabular}{|c|c|c|c|c|}
\hline \multicolumn{5}{|c|}{ Report } \\
\hline $\begin{array}{l}\text { Participants } \\
\text { Gender }\end{array}$ & \multicolumn{2}{|c|}{ Teachers' Instructional Strategies } & Process Skills Post-Test & Academic Achievement Post-Test \\
\hline \multirow{12}{*}{ Male } & \multirow{4}{*}{ Direct Instruction } & Mean & 62.9055 & 52.8819 \\
\hline & & $\mathbf{N}$ & 127 & 127 \\
\hline & & Std. Deviation & 14.43894 & 14.24481 \\
\hline & & Mean & 66.6667 & 61.2519 \\
\hline & \multirow[t]{2}{*}{ Cooperative learning } & $\mathbf{N}$ & 135 & 135 \\
\hline & & Std. Deviation & 14.89014 & 17.00822 \\
\hline & \multirow{4}{*}{ Guided-Inquiry } & Mean & 66.2560 & 66.8480 \\
\hline & & $\mathbf{N}$ & 125 & 125 \\
\hline & & Std. Deviation & 15.37955 & 17.75508 \\
\hline & & Mean & 65.2997 & 60.3127 \\
\hline & \multirow[t]{2}{*}{ Total } & $\mathbf{N}$ & 387 & 387 \\
\hline & & Std. Deviation & 14.96137 & 17.32732 \\
\hline \multirow{11}{*}{ Female } & \multirow{4}{*}{ Direct Instruction } & Mean & 61.4600 & 66.3000 \\
\hline & & $\mathbf{N}$ & 50 & 50 \\
\hline & & Std. Deviation & 13.42281 & 15.97351 \\
\hline & & Mean & 63.6863 & 66.3725 \\
\hline & \multirow[t]{2}{*}{ Cooperative learning } & $\mathbf{N}$ & 51 & 51 \\
\hline & & Std. Deviation & 15.91413 & 18.02660 \\
\hline & \multirow{3}{*}{ Guided-Inquiry } & Mean & 64.6774 & 62.4194 \\
\hline & & $\mathbf{N}$ & 31 & 31 \\
\hline & & Std. Deviation & 15.51856 & 18.45494 \\
\hline & \multirow[b]{2}{*}{ Total } & Mean & 63.0758 & 65.4167 \\
\hline & & $\mathrm{N}$ & 132 & 132 \\
\hline
\end{tabular}

